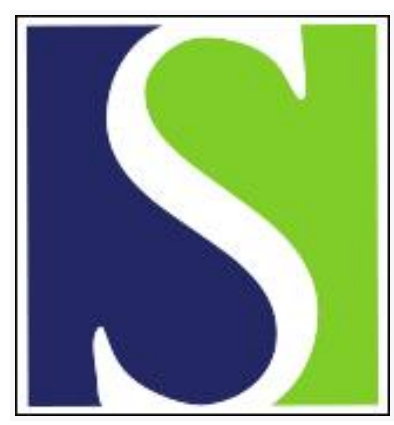

Scand J Work Environ Health 1981;7(4):241-251

https://doi.org/10.5271/sjweh.2552

Issue date: Dec 1981

Biological monitoring in the identification of the cancer of individuals exposed to chemical carcinogens.

by Vainio H, Sorsa M, Rantanen J, Hemminki K, Aitio A

Key terms: alkylation; biological monitoring; cancer; chemical carcinogen; chromosome aberration; exposure; genotoxicity; mutagenicity; nucleic acid; oncodevelopmental protein; protein; risk assessment; sister chromatid exchange; sperm morphology

This article in PubMed: www.ncbi.nlm.nih.gov/pubmed/6753140 


\title{
Biological monitoring in the identification of the cancer risk of individuals exposed to chemical carcinogens'
}

\author{
by Harri Vainio, MD, Marja Sorsa, PhD, Jorma Rantanen, MD, \\ Kari Hemminki, MD, and Antero Aitio, $\mathrm{MD}^{2}$
}

\begin{abstract}
VAINIO H, SORSA M, RANTANEN J, HEMMINKI K, AITIO A. Biological monitoring in the identification of the cancer risk of individuals exposed to chemical carcinogens. Scand $j$ work environ health 7 (1981) 241-251. The effects of genotoxic agents may be manifest, through genetic damage in somatic or germinal cells, as tumors, malformations, genetic defects, or reduced fertility. The present article discusses the currently available theoretical and practical possibilities for measuring genotoxic exposures and their early effects on the human body. The authors also express their views about the actions necessary in cases of demonstrated occupational exposure to genotoxic chemicals.
\end{abstract}

Key terms: alkylation/protein, alkylation/nucleic acids, chromosome aberrations, genotoxicity, mutagenicity, oncodevelopmental proteins, risk assessment, sister chromatid exchanges, sperm morphology.

\section{Exposure to genotoxins}

There are approximately 50,000 synthetic chemical compounds in common use, and about 1,000 more are introduced every year (37). In addition, potent mutagens and carcinogens can be found among such natural substances as plant alkaloids, mycotoxins, and flavonoids; and the curing or heating of foodstuffs may generate a variety of genotoxins, ${ }^{3} \mathrm{eg}$, nitrosamines, or different amino acid derivatives. The genotoxic effect of smoking has been indisputably demonstrated (5), and coffee, tea, cocoa, and alcoholic beverages contain

1 Biological monitoring comprises estimation of the absorbed amount of a chemical and the early (reversible) effects on exposed individuals.

2 Institute of Occupational Health, Helsinki, Finland.

3 We have used the word genotoxin to indicate a genotoxic chemical, ie, a chemical causing damage in genetic material, probably by a mechanism involving binding to DNA (deoxyribonucleic acid).

Reprint requests to: $\mathrm{Dr} \mathrm{H}$ Vainio, Institute of Occupational Health, Haartmaninkatu 1, SF00290 Helsinki 29, Finland. ingredients suspected of genotoxicity. Furthermore, bacteria in the intestine apparently produce, eg, carcinogenic nitrosamines from nitrite and amine in food. This ubiquitous exposure to genotoxic chemicals may play a role in the genesis of apparently "spontaneous" tumors, malformations, and genetic diseases although the levels of exposure are generally low. In contrast, the levels of exposure may be considerably higher in the occupational environment (23). Therefore, it is not unexpected that, with 16 out of 18 chemicals shown to cause cancer in man, the exposure is mainly occupational (27). Cancer risk is thus, in general, more apparent in relation to occupational exposure.

In this article we have attempted to provide an account of the practical possibilities currently available for estimating the exposure of a population to genotoxic agents and for detecting some of the early biological effects of such exposures. We have also briefly stated our views about the actions necessary in cases of demonstrated early effects of occupational genotoxic exposure. 


\section{Measurement of abnormal amounts of chemicals}

Chemical or its metabolite in expired air, blood or urine

Few of the substances suspected to involve a risk of cancer are analyzed routinely from biological samples (table 1), more because of the meager knowledge available on toxicokinetics than because of a lack of analytical ability. In many cases, too, the analysis of biological samples can be troublesome, mainly due to matrix effects and the limited availability of tissue for analysis. Thus, eg, although measuring the benzene burden of the body by analyzing benzene in expired air is relatively simple, a simultaneous measurement of the blood benzene concentration has been impossible (2).

The time and the mode of sampling for biological monitoring are largely determined by the toxicokinetics of the agent. For example from 80 to $100 \%$ of absorbed tetrachloroethylene is excreted unchanged in the air expired from the body. A small amount accumulates however in adipose tissue, wherefrom it is only slowly eliminated. The amount of accumulated tetrachloroethylene is best assessed from blood samples taken the morning after exposure; the compound measured is the chemical itself, tetrachloroethylene (41).

Trichloroethylene, on the other hand, is transformed to trichloroethanol and tri- chloroacetic acid in the organism so that only about $30 \%$ leaves the body unchanged. The best estimates of accumulated trichloroethylene are obtained with measurements of urinary trichoroethanol and/or trichloroacetic acid. The apparent half-times of trichloroethanol and trichloroacetic acid in the body are around 12 and $100 \mathrm{~h}$, respectively. Thus the urinary trichloroethanol concentration reflects the amount of trichloroethylene absorbed during a couple of preceding days, whereas the measurement of trichloroacetic acid illustrates the accumulation of several days. Since the half-time of trichloroethylene itself is very short in the blood, trichloroethylene determinations in blood are unsuitable for biological monitoring (41).

Benzene accumulates in adipose tissue, from where it is gradually released. It is partly excreted into the expired air and partly metabolized to phenol. In principle, the uptake of benzene can be estimated from the urinary phenol concentration or from the benzene concentration in the blood or expired air. Experience has shown that when the 8-h average benzene concentration of inspired air is less than about $10 \mathrm{~cm}^{3} / \mathrm{m}^{3}$, the phenol formed from benzene is masked by phenol from other sources. Thus the only alternative is to measure the benzene concentration in the blood or in expired air, the latter of which is more practical. A sample from the following morning reflects the concentration of benzene in the body adipose tissue

Table 1. Determination of suspected carcinogenic chemicals in body fluids (62).

\begin{tabular}{llll}
\hline Chemical & Analysis & $\begin{array}{l}\text { Reference } \\
\text { value a }\end{array}$ & Remarks \\
\hline Arsenic & U-As & $<0.7 \mu \mathrm{mol} / \mathrm{l}$ & $\begin{array}{c}\text { Measures total arsenic } \\
\text { Insensitive, nonspecific }\end{array}$ \\
Benzene & U-Phenol & $<100 \mu \mathrm{mol} / \mathrm{I}$ & \\
Cadmium & U-Cd & $<5 \mathrm{nmol} / \mathrm{I}$ & \\
& B-Cd & $<10 \mathrm{nmol} / \mathrm{I}$ & \\
Chromium & U-Cr & $<100 \mathrm{nmol} / \mathrm{I}$ \\
Nickel & U-Ni & $<100 \mathrm{nmol} / \mathrm{I}$ \\
Styrene & U-Mandelic acid & $<100 \mu \mathrm{mol} / \mathrm{I}$ \\
Tetrachloroethylene & B-Tetrachloroethylene & $-\mathrm{b}$ \\
Trichloroethylene & U-Thichloro-acetic acid & - & \\
\hline
\end{tabular}

a For nonexposed persons.

b Unmeasurable by routine gas chromatography. 
and gives an estimate of the benzene load of approximately five preceding days (2).

A prerequisite for biological monitoring is the occurrence of measurable amounts of the chemical or its metabolite in the blood, urine, or the expired air. Chemicals that exert their effect locally, at the site of deposition, without a general disposition in the organism, therefore, may not be monitored biologically. Thus, eg, the rather insoluble nickel compounds, metallic nickel, nickel oxide, and nickel subsulfide, form local deposits on the mucous membranes of the respiratory tract. After a latency period of 5-40 a, they may cause tumors there. The blood and urine nickel concentrations usually remain in the normal range however. In contrast, water-soluble nickel compounds (sulfate, chloride) are readily absorbed from the respiratory passages into the blood stream and excreted in the urine. Therefore exposure to water-soluble nickel compounds can be monitored without difficulty with urine analyses (55). Similarly, the solubility of various chromates differ widely. In other words, the kinetics of different salts of a single inorganic compound may be very different. Therefore it is imperative to know exactly the specific species of the chemical in the air before conclusions can be drawn on absorbed amounts based on data from biologial monitoring. Although a positive finding always indicates qualitatively that exposure has occurred, a negative finding does not necessarily exclude exposure.

\section{Determination of mutagenicity in biological fluids}

With the advent of some relatively simple assays for mutagenicity, a new avenue has been opened for semiquantitative measurements of genotoxic chemicals. Urine analyses are the most widely used, as many mutagenic agents or their metabolites are excreted in the urine.

Most mutagenic or carcinogenic substances are present in the urine as conjugates. As the conjugates are, with few exceptions, biologically inactive, they have to be broken down. For the assaying of the mutagenicity, the urine sample must be concentrated because methodological problems preclude the use of large volumes of urine. The nonionic Amberlite resin XAD-2 has proved useful in the concentration (61); it adsorbs most conjugates, and nonpolar compounds as well. In contrast amino acids are not adsorbed in amounts interfering in the subsequent assay of mutagenicity.

Many different test systems have been used for studying the mutagenicity of urine concentrates. Yamasaki \& Ames (61) showed that urine concentrates of smokers were mutagenic with the Salmonella/liver homogenate plate test. The degree of mutagenic activity in the urine is dependent on the extent (9) and the mode of smoking, eg, the extent of inhalation (61). The urine of patients receiving antineoplastic drugs, eg, cyclophosphamide, is mutagenic in bacterial tests $(15$, 53). Mutagenicity has also been detected in the urine of persons occupationally exposed to anesthetic gases or rubber chemicals (table 2). With the use of the fluctuation test, which is $10-100$ times more sensitive than the normal Ames plate test (20), mutagenic activity has been detected in the urine of nurses who administer cytostatic drugs (15).

When mutagenicity in the urine is used as an indicator of occupational exposure to genotoxic chemicals, smoking is the most important confounding factor. However, smoking induces mutations preponderantly in bacterial strains that are sensitive to frame-shift mutations $(16,61)$. Consequently, it may be possible to differentiate between mutagenic activities that originate from occupational exposures and smoking by employing both bacterial strains sensitive to base-pair and to frameshift mutations. This separation was accomplished in a study of workers in the rubber industry (16). It is known that the urinary mutagenicity is increased in some severe liver diseases (19), but such rare cases are not likely to cause errors in normal populations.

The difference between chemical analysis and the analysis of urinary mutagenicity is that the Iatter has to be regarded, for the moment, as a qualitative or, at best, a semiquantitative method. Another difference between the two analytical approaches lies in their different specificities. The mutagenicity assay is specific with 
Table 2. Examples of occupational groups with microbiologically demonstrated urinary mutagenicity.

\begin{tabular}{|c|c|c|}
\hline Occupational group & Method & Reference \\
\hline Anesthesiologists & Ames test & McCoy et al (38) \\
\hline $\begin{array}{l}\text { Chemical industry (epichlorohydrin- } \\
\text { exposed workers) }\end{array}$ & Ames test & Kilian et al (32) \\
\hline Nurses administering cytostatic drugs & Fluctuation test & Falck et al (15) \\
\hline Coke plant workers & Ames test & Møller \& Dybing (40) \\
\hline Rubber workers & Fluctuation test & Falck et al (16) \\
\hline
\end{tabular}

respect to the nature of a health hazard (ie, risk of mutations), but it is nonspecific as far as the identity of the exposing chemical is concerned. Thus, the chemical(s) responsible for the mutagenicity must be identified separately. However, the nonspecificity of urinary mutagenicity assays is not always a weakness; in multiexposure environments the total genotoxicity caused by different chemicals may be monitored with a single, relatively simple test. One has to bear in mind, however, that a mutagenicity assay of urine is only valid when the exposing chemicals appear in the urine in a form which is or can be activated into a mutagenic form. A negative result does not necessarily exclude the possibility of genotoxic exposure.

The mutagenicity testing of biological samples other than urine has, for the moment, little practical importance.

\section{Products of protein alkylation}

A general property of genotoxic compounds seems to be the presence of electrophilic groups which tend to react covalently with nucleophilic groups in, eg, amino acids $\left(-\mathrm{SH},-\mathrm{OH},=\mathrm{NH}\right.$, and $\left.-\mathrm{NH}_{2}\right)$ and nucleic acids (eg, $=\mathrm{NH}$ and $-\mathrm{OH})$. In a large group of genotoxic chemicals, this electrophilic moiety is an alkyl group; hence the covalent binding results in the alkylation of, eg, peptides, proteins, DNA, and RNA (ribonucleic acid). The alkylated proteins and peptides (the most prevalent of which is glutathione) are degraded, and the alkylated amino acids liberated are excreted in the urine or bile.

Genotoxic exposure can be estimated by the measurement of alkylated proteins in the blood. Since there is a certain relationship between the alkylation of amino acids and the alkylation of nucleic acids, the results may also be used for the estimation of the genotoxic risk of exposed workers. The team of Prof L Ehrenberg has pioneered in the development of methods measuring hemoglobin alkylation. Ethylene oxide (13) and methyl methanesulfonate (52) were found to react directly with nucleophilic groups in experimental animals. In contrast, ethene, propene, dimethylnitrosamine (46), and vinyl chloride (47) reacted with hemoglobin only after transformation into reactive metabolites.

Hemoglobin alkylation has also been measured in the blood of people exposed to ethylene oxide (7). Although the ethylene oxide concentrations, in the work environment were as low as 5-10 ppm, it was possible to isolate alkylated residues of the amino acid histidine from the hemoglobin of the exposed groups. The measurement of hemoglobin alkylation is a laborious procedure, and it has not yet been adapted to routine measurements.

Abundance and long half-time are regarded as the special advantages of hemoglobin as an alkylation target. Proteins with a shorter half-time, eg, the serum proteins (22), are more suitable for demonstrating exposures of short duration. Another advantage of certain serum proteins might be that they are synthesized in liver cells, which have the largest capacity of metabolic activation of indirectly alkylating agents.

There are many studies in which alkylated amino acid residues have been measured in the urine $(13,29)$. Alkyl derivatives of cysteine and $\mathrm{N}$-acetylcysteine, ie, thioethers, have been demonstrated in the 
urine of, eg, rubber workers (56) and methyl chloride-exposed workers (10). It is not possible to determine what part of the urinary alkylcysteines is derived from proteins and what from glutathione, and therefore their measurement provides only indirect information about the genotoxic exposure.

Since large volumes of urine can easily be collected, the analysis of alkylated amino acid residues in the urine may have practical importance as a means of evaluating the absorption of potentially alkylating chemicals.

\section{Products of nucleic acid alkylation}

Products of the reaction of genotoxins with nucleic acids are broken down spontaneously and/or enzymatically. Alkylation of the nitrogen atom at position 7 of quanine in DNA renders the glycosidic bond susceptible to hydrolysis and results in a release of the $\mathrm{N}$-alkylguanine. The half-time of $\mathrm{N}$-methylguanine in the body is about $2 \mathrm{~d}$. Increasing amounts of $\mathrm{N}-7$ methylguanine have been detected in the urine of rats after the administration of dimethylnitrosamine, methyl methanesulfonate, and some other methylating agents $(8,52)$. However, because methylation of guanine proceeds even spontaneously, the excretion of methylated guanine is not a very sensitive indicator of alkylation. Because other alkylated nucleic acid derivatives (besides the methylated ones) do not seem to be formed spontaneously, they may perhaps be used as indicators of the extent of nucleic acid alkylation and the ensuing genotoxic risk.

Two kinds of methods are available for the identification of (alkylated and other) derivatives of nucleic acid bases excreted into the urine, the traditional biochemical methods and the newly developed sensitive radioimmunologic methods (50). The radioimmunologic approach involves the use of specific antibodies for each adduct and will probably be greatly facilitated by the use of monoclonal antibody production techniques. As yet, however, the analysis of urinary nucleic acid derivatives is not a routine method.

\section{Measurement of early effects of genotoxic agents}

\section{Oncodevelopmental proteins}

Many tumors release into circulation various compounds not produced by normal tissues. These compounds include hormones and their precursors (vasopressin, gonadotropin, proadrenocorticotropin), enzymatically active proteins (diamineoxidases, phosphatases, creatine kinases, amylases, hexosaminidases, glutamyl transferases), and proteins without known enzymatic activity [ $\alpha$-fetoprotein, carcinoembryonic antigen (CEA), tissue polypeptide antigen, $\beta$-microglobulin]. Moreover, the production and urinary secretion of polyamines is increased in many tumorous diseases. Many of these antigens (the term reflects the fact that the measurement of most of them is based on their antigenic properties) have originally been proposed as specific markers for certain tumors, but in the course of time it has almost invariably been established that they are encountered in other diseases as well. In addition, small amounts of these antigens can be detected even in healthy persons. Although the amount of antigens may be very high in tumorous diseases, the considerable nonspecificity has led to the application of tumor antigen determinations almost exclusively in the follow-up of established antigen-producing tumors.

Of the tumor antigens, CEA has received the most attention. Increased concentrations of CEA are the most common in connection with intestinal (colonic, pancreatic, hepatic) tumors. A high level of CEA, however, is not specific to tumorous diseases but is encountered also in, eg, inflammatory disorders of the intestines. From the point of view of chemical carcinogenesis, it is interesting to note that, on the average, smokers have higher CEA concentrations than nonsmokers [For references, consult the Proceedings of the First International Conference on the Clinical Uses of Carcinoembryonic Antigen (63)]. Slightly increased CEA values are likewise often encountered in heavy drinkers. Furthermore one study has reported higher CEA concentrations in styrene-exposed workers than in a reference group standardized for age, sex, smoking 
and drinking habits, and former and current diseases (1). Vinyl chloride-exposed workers have also been found to have increased CEA concentrations (48). It still remains to be studied whether tumor antigen determinations can be used for identifying the early biological effects encountered by chemically exposed workers, ie, for the screening of risk groups.

\section{Early cytogenetic response}

Analysis of somatic chromosome aberrations. Most of the chemicals that cause visible chromosome damage, ie, that are clastogenic, are known or suspected carcinogens (table 3 ). This phenomenon forms the basis for using clastogenic effects as indicators of carcinogenic risk.

Virtually the only direct method for the demonstration of genetic damage in human somatic cells is the chromosome analysis of blood lymphocytes cultured in the presence of a mitogen. The method has two drawbacks. First, the reproducibility of individual results, at least between laboratories, tends to be poor, and second, a previous exposure of the subjects to radiation or genotoxic chemicals and latent or recent viral infections can affect the results.

The study of lymphocyte chromosome aberrations requires a careful study design, a detailed analysis of exposures, and simultaneous examination of a reference group. The number of metaphases scored should be at least 100 per subject. It is advisable to harvest the cells after $48-50 \mathrm{~h}$ of cultivation so that most of the lymphocytes can be obtained in their first metaphase. In this manner, possible selection or in vitro damage during cultivation is kept to a minimum. One must relate the different types of structural intra- and interchromosome changes separately when reporting results of the analysis [For methodology, consult the article of Evans \& O'Riordan (14)].

The dose-response relationships between radiation exposure and chromosome changes in lymphocytes have been adequately documented; therefore, chromosome analyses are used at present for biological dosimetry.

The capacity of various chemical mutagens to induce DNA strand breakage in chromosomes varies markedly. Frequently, the effect of chemical mutagens is delayed, ie, chromosome breaks may not appear until some cell cycles after the exposure. Furthermore, the potency of chemicals as clastogens may vary with the cell cycle. Therefore, it is obvious that a common dosimetry for different chemical mutagens is unachievable and that a characteristic dose-response relationship must be determined for each chemical.

Table 3. Cases of increased frequency of somatic chromosome changes in some exposed groups (in historical order).

\begin{tabular}{|c|c|c|}
\hline Exposure & Group & Reference \\
\hline $\begin{array}{l}\text { Benzene } \\
\text { Radiation }\end{array}$ & Workers & Vigliani \& Saita (58) \\
\hline $\begin{array}{l}\text { Atomic bomb } \\
\text { Therapeutic }\end{array}$ & $\begin{array}{l}\text { Survivors } \\
\text { Patients }\end{array}$ & $\begin{array}{l}\text { Bloom et al (4) } \\
\text { Buckton et al (6) }\end{array}$ \\
\hline $\begin{array}{l}\text { Cytostatics } \\
\text { Ethylene oxide }\end{array}$ & $\begin{array}{l}\text { Patients } \\
\text { Workers }\end{array}$ & $\begin{array}{l}\text { Jensen (28) } \\
\text { Ehrenberg \& Hällström (12) }\end{array}$ \\
\hline \multicolumn{3}{|l|}{ Drugs } \\
\hline $\begin{array}{l}\text { Chlorpromazine } \\
\text { Phenylbutazone }\end{array}$ & $\begin{array}{l}\text { Patients } \\
\text { Patients }\end{array}$ & $\begin{array}{l}\text { Nielsen et al ( } 43) \\
\text { Stevenson et al }(54)\end{array}$ \\
\hline $\begin{array}{l}\text { Arsenic } \\
\text { Lead } \\
\text { Chloroprene } \\
\text { Vinyl chloride } \\
\text { Chromium } \\
\text { Epichlorohydrin } \\
\text { Styrene } \\
\text { Organic solvents }\end{array}$ & $\begin{array}{l}\text { Patients } \\
\text { Workers } \\
\text { Workers } \\
\text { Workers } \\
\text { Workers } \\
\text { Workers } \\
\text { Workers } \\
\text { Laboratory personnel }\end{array}$ & $\begin{array}{l}\text { Petres et al (49) } \\
\text { Schwanitz et al (51) } \\
\text { Katosova (31) } \\
\text { Ducatman et al (11) } \\
\text { Bigaliev et al (3) } \\
\text { Kucerova et al (33) } \\
\text { Meretoja et al (39) } \\
\text { Funes-Cravioto et al (18) }\end{array}$ \\
\hline
\end{tabular}


As for the significance of demonstrated chromosome aberrations in the evaluation of health risks, it is known that, although some kind of dose-response relationship between chromosome aberrations and cancer incidence can be found (45), such a relationship has been determined at the group level only. Still, chromosome analyses may reveal individual sensitivities or exceptionally high levels of exposure. At present we do not yet have sufficient information about the biological validity of chromosome damage as an indicator of individual health risk. However, cytogenetic analyses are justified, on a group basis, when clastogenic exposure is suspected. Interpreting the results requires familiarity with the occupational environment and knowledge of the toxicologic properties of the exposing agents. On the group level, the demonstration of chromosome aberrations can be considered proof of genotoxic risks requiring actions to decrease exposure.

Analysis of sister chromatid exchanges. Sister chromatid exchanges (SCEs) reflect intrachromosome rearrangements of the DNA helices, and their determination has proved to be more sensitive than the conventional metaphase analysis, especially directly following the exposure in question. The SCE frequency in the lymphocytes has been found to remain at a high level for 4-16 weeks after exposure, whereas gross structural chromosome changes can persist for several years. SCEs and chromosome aberrations do not always covariate, especially in cases involving ionizing radiation, which effectively induces chromosome damage but almost no SCEs. The molecular mechanism of SCE induction is unknown; still it is evident that SCEs are a sensitive indicator of damage to DNA. Variations in SCE frequencies have been systematically monitored for cancer patients on cytostatics (eg, 42). Demonstrated SCE-inducing agents include mono- and bifunctional alkylating drugs [eg, mitomycin C, busulfan, 1-[2chloroethyl-3-(4-methyl-cyclohexyl)]-1-nitrosourea (CCNU), cyclophosphamide, chlorambucil, melphalan, and thiotepa] and the antibiotic adriamycin, whereas neither the antimetabolites methotrexate and cy- tosine arabinoside nor the inhibitors of nucleic acid synthesis actinomycin $\mathrm{D}$ and bleomycin affect the SCE frequency (34).

The SCE frequency has been shown to be significantly higher in nurses who handle cytostatic drugs than in office personnel (44). Also persons who use organic solvents in laboratories have an increased SCE frequency (18); the same applies to sterilization workers who handle ethylene oxide (34). Many studies have revealed above-normal SCE frequencies in smokers $(17,26,34)$. On the other hand, SCE values not exceeding those of referents have been observed in operating room personnel (34), toluene-exposed printing operators (36), and xylene-exposed workers in the paint industry (21).

Quite recently, promising results have been obtained on the prospect of using the SCE method for estimating individual cancer risk (24). The lymphocyte SCE response to smoke condensate treatment was found to be significantly higher in smokers with lung cancer than in healthy smokers or nonsmokers. This result suggests that smokers with lung cancer develop DNA lesions, measured in terms of the SCE response, more readily than those smokers without lung cancer.

The investigation of gross chromosome aberrations and SCEs constitutes a promising means of biological monitoring in cases of mutagen exposure. It is apparent that the methods involved are mutually complementary. Which of the two is best suited depends upon the type and duration of exposure and on the time lag between exposure and analysis.

\section{Morphology of sperm}

Seminal fluid analyses represent the only possibility to evaluate genetic damage in human germinal cells. There is experimental evidence that abnormalities of sperm shape and size closely mirror the genome damage brought about by disturbances in spermatogenesis and that the propagation of abnormal sperm can be considered an effect of mutagen exposure in the germinal tissue (60). With the application of special techniques, it is also possible to detect abnormalities in meiotic divisions at spermatocytes from ejaculates 
(30) or testicular biopsies (25). Smoking and exposure to lead or dibromochloropropane have been shown to cause abnormalities in sperm morphology and a decrease in sperm motility $(35,57,59)$.

Although the remarkable variation in sperm counts poses special problems for experimental set-up and the selection of a reference group and special effort is needed to motivate subjects to take part in the examination, seminal fluid analyses should certainly be applied much more in cases of suspected mutagen exposure. It is still a matter of controversy whether higher proportions of abnormal sperm can be considered to indicate an increased risk of genetic damage, but the contribution to lowered fertility is indisputable.

\section{Interpretation of data and ensuing action}

The primary prevention of genotoxic manifestations is the elusive and perhaps the most challenging goal in occupational health practice. The available possibilities to evaluate individual risk (ie, the probability of adverse health effects) are still meager. Because the diseases concerned are often grave, and mostly irreversible, the diagnostic measures tend to be too late to benefit the individual. Because of

B IOLOG I CAL MONITORING

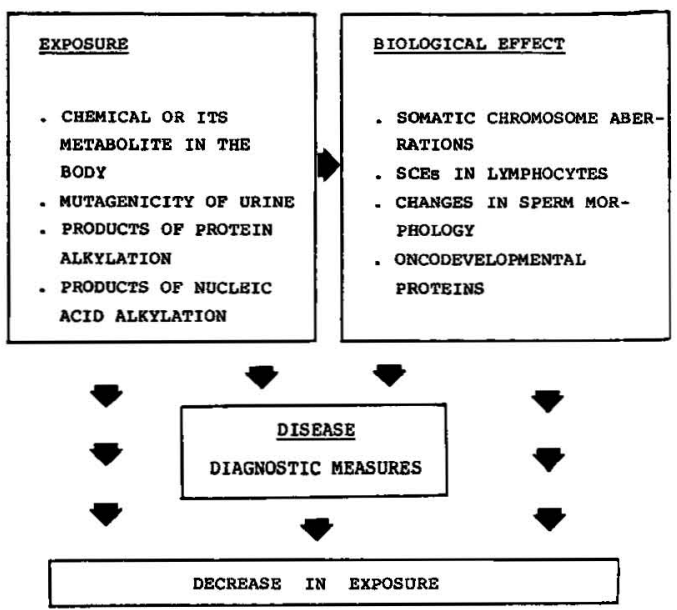

Fig 1. Perspectives for the biological monitoring of genotoxic exposures. (SCEs = sister chromatid exchanges) the long latency periods, usually little remains to be done even for other individuals similarly exposed, but not (yet) with the fulminant disease. That is, diagnostic measures may not prevent epidemics. Methods of biological (and environmental) monitoring are therefore urgently needed for the protection of the health of workers.

Biological monitoring of genotoxins is in a phase of rapid development. Most of the methods discussed in the present report are still in the experimental stage.

The measurement of the absorbed amount can be carried out with routine methods for a few genotoxic chemicals only (fig 1). Much work is needed to establish analytical methods and provide toxicokinetic information on others.

The primary value of both urinary thioether and mutagenicity is their signal function; which means that when an increase in the urinary thioether excretion or mutagenic activity is found, it may be concluded that exposure and absorption of electrophilic and mutagenic substances has occurred. But these tests do not tell anything about possible genotoxic effects within the organism, ie, they are not, in any way, effect indicators.

The cytogenetic methods - the determination of somatic chromosome aberrations and SCEs - have an established role in radiation control. Automation of the chromosome analysis would mean a major breakthrough in their application in the biological monitoring of genotoxins. The utility of amino acid and nucleic acid adducts in biological monitoring must still be clarified. Analyses of oncodevelopmental proteins also need further study.

At present it seems feasible that exposure to genotoxins be monitored by traditional analytical methods and, where these are not available, the mutagenicity of urine be studied. On certain occasions, urinary mutagenicity analyses may prove to be superior to chemical analysis, even when the latter is available; this might be the case when the exposure is multiple, but still well defined. Risk identification might then be based on one analysis rather than a multitude of chemical analyses. In certain risk occupations, cytogenetic analyses (primarily those of SCE) should be performed. All the other approaches de- 
scribed need further experimental study before being applied in routine work.

What is the right course of action in cases of positive findings in biological monitoring? If the findings indicate unequivocally that a group of workers has been exposed, the first step is to lower the exposure. If measurements show aboveaverage exposure for only one individual, the causative factors must be traced. Even in similar work, the exposure, and the absorbed amount of chemical, varies between individuals; in addition, individuals' sensitivity to chemicals differs. Sources of exceptionally high exposures of individual workers must be determined, and the levels of exposure lowered. When individuals with high numbers of chromosome abnormalities (or SCEs) are encountered at average or low exposures, the situation is complicated, as too little is currently known on the relationship between susceptibility to chromosome changes and cancer in the individual. It is naturally clear that "playing it safe," ie, lowering exposure, should be attempted whenever high frequencies of chromosome abnormalities are detected. Thus, the minimization of genotoxic exposure is always warranted.

\section{References}

1. Andersson HA, Lorimer W, Snyder J, Selikoff IJ. Levels of carcinoembryonic antigen in styrene workers. In: Proceedings of Medichem 4th international conference, Haifa Sept. 7-10, 1976, abstract $R 37$.

2. Berlin M, Tunek A. Benzene. In: Aitio A, Riihimäki V, Vainio $H$, ed. Biological monitoring and health surveillance of workers exposed to chemicals. Hemisphere, Washington, DC, in press.

3. Bigaliev $\mathrm{AB}$, Turebaev MN, Bigalieva RK, Elemesova M. Cytogenetic examination of workers engaged in chrome production [in Russian]. Genetika 13 (1977) 545-547.

4. Bloom AD, Neriishi S, Awa AA. Chromosome aberrations in leukocytes of older survivors of the atomic bombings of Hiroshima and Nagasaki. Lancet 2 (1967) 802805 .

5. Bridges BA, Clemmesen $J$, Sugimura $T$. Cigarette smoking - Does it carry a genetic risk? Mutat res 65 (1979) $71-81$. (ICPEIMC no 3).

6. Buckton $\mathrm{KE}$, Langlands AO, Smith PG, McLelland J. Chromosome aberrations following partial and whole body X-irradiation in man: Dose-response relationships. In: Evans HJ, Court Brown WM, McLean
AS, ed. Human radiation cytogenetics. North Holland, Amsterdam 1967, pp 122135.

7. Calleman CJ, Ehrenberg L, Jansson B, Osterman-Golkar S, Segerbäck D, Svensson $\mathrm{K}$, Wachtmeister CA. Monitoring and risk assessment by means of alkyl groups in hemoglobin in persons occupationally exposed to ethylene oxide. J environ pathol toxicol 2 (1978) 427-442.

8. Craddock VM, Magee PN. Effect of administration of the carcinogen dimethylnitrosamine on urinary 7-methylguanine. Biochem j 104 (1967) 435-440.

9. Doorn $\mathrm{R}$ van, Bos RP, Leijdekkers C-M, Wagenaas-Zegers MAP, Theuws JLG, Henderson PT. Thioether concentration and mutagenicity of urine from cigarette smokers. Int arch occup environ health 43 (1979) $159-166$.

10. Doorn $R$ van, Borm PJA, Leijdekkers C-M, Hendersson PT, Reuvers J, van Bergen TJ. Detection and identification of S-methylcysteine in urine of workers exposed to methyl chloride. Int arch occup environ health 46 (1980) 99-109.

11. Ducatman A, Hirschorn K, Selikoff IJ. Vinyl chloride exposure and human chromosome aberrations. Mutat res 31 (1975) $163-168$.

12. Ehrenberg L, Hällström T. Haematological studies on persons exposed to ethylene oxide. International atomic energy agency 1967, pp 327-334. (SM 92/26).

13. Ehrenberg L, Hiesche KD, Osterman-Golkar S, Wennberg I. Evaluation of genetic risks of alkylating agents: Tissue doses in the mouse from air contaminated with ethylene oxide. Mutat res 24 (1974) 83-103.

14. Evans HJ, O'Riordan ML. Human peripheral blood lymphocytes for the analysis of chromosome aberrations in mutagen tests. Mutat res 31 (1975) 135-148.

15. Falck K, Gröhn P, Sorsa M, Vainio H, Heinonen E, Holsti LR. Mutagenicity in urine of nurses handling cytostatic drugs. Lancet 1 (1979) 1250-1251.

16. Falck K, Sorsa M, Vainio H, Kilpikari I. Mutagenicity in urine workers in rubber industry. Mutat res 79 (1980) 45-52.

17. Fredga K, Dävring L, Sunner M, Bengtsson B, Elinder C-G, Sigtryggsson P, Berlin M. Kromosomförändringar hos arbetare exponerade för drivmedel och avgaser. Lunds Universitet, Lund 1979, pp 1-29. (Lunds. Universitet rapport $\mathrm{nr} 790320$ ).

18. Funes-Cravioto F, Kolmodin-Hedman B, Lindsten J, Nordenskjöld M, Zapata-Gayon C, Lambert B, Nordberg E, Olin R. Chromosome aberrations and sister chromatid exchange in workers in chemical laboratories and a rotoprinting factory and in children of women laboratory workers. Lancet 1 (1977) 322-325.

19. Gelbart SM, Sontag SJ. Mutagenic urine in cirrhosis. Lancet 1 (1980) 894-896.

20. Green MHL, Muriel WJ. Mutagen-testing using trp + reversion in Escherichia coli. Mutat res 38 (1976) $3-32$. 
21. Haglund U, Lundberg I, Zech L. Chromosome aberrations and sister chromatid exchanges in Swedish paint industry workers. Scand j work environ health 6 (1980) $291-298$.

22. Hemminki $\mathrm{K}$, Savolainen $\mathrm{H}$. Alkylation of rat serum proteins by dimethylnitrosamine and acetyl aminofluorene. Toxicol lett 6 (1980) $433-437$.

23. Hemminki K, Sorsa M, Vainio H. Genetic risks caused by occupational chemicals. Scand j work environ health 5 (1979) 307327.

24. Hopkin JM, Evans HJ. Cigarette smokeinduced DNA damage and lung cancer risks. Nature 283 (1980) 388-390.

25. Hultén M, Luciani J. On the possibilities of detecting chromosome abnormalities induced by environmental agents in human germ line cells. In: Berg $\mathrm{K}$, ed. Genetic damage in man caused by environmental agents. Academic Press, New York, NY 1979, pp 143-186.

26. Husgafvel-Pursiainen K, Mäki-Paakkanen J, Norppa H, Sorsa M. Smoking and sister chromatid exchange. Hereditas 92 (1980) $247-250$.

27. International Agency for Research on Cancer. Chemicals and industrial processes associated with cancer in humans. Lyon 1979, pp 1-71. (IARC monographs supplement 1 , volumes 1 to 20 ).

28. Jensen MK. Chromosome studies in patients treated with azathioprine and amethropterin. Acta med scand 182 (1967) $445-455$.

29. Jones SR. The metabolism of biological alkylating agents. Drug metab rev 2 (1973) $71-100$.

30. Kap RW Jr. Detection of aneuploidy in human sperm. Environ health perspect 31 (1979) $27-31$.

31. Katosova LD. Cytogenetic analysis of peripheral blood of workers engaged in the production of chloroprene. Gig tr prof zabol 10 (1973) $30-39$.

32. Kilian DJ, Pullin TG, Connor TH, Legator MS, Edwards HN. Mutagenicity of epichlorohydrin in the bacterial assay system: Evaluation by direct in vitro activity and in vivo activity of urine from exposed humans and mice. Mutat res 53 (1978) 72.

33. Kucerova M, Zhurkov VS, Polikova Z, Ivanova JE. Mutagenic effect of epichlorohydrin: II. Analysis of chromosomal aberrations in lymphocytes of persons occupationally exposed to epichlorohydrin. Mutat res 48 (1977) 355-360.

34. Lambert B, Lindblad A, Holmberg $\mathrm{K}$, Francesconi D. Use of sister chromatid exchange to monitor human populations for exposure to toxicologically harmful agents. In: Wolff S, ed. Sister chromatid exchange. John Wiley \& Sons, New York, NY (in press)

35. Lancaranjan I, Popescu H, Gavanescu O, Klepsch I, Serbanescu M. Reproductive ability of workmen occupationally exposed to lead. Arch environ health 30 (1975) 396401.
36. Mäki-Paakkanen J, Husgafvel-Pursiainen KL, Kalliomäki P-L, Tuominen J, Sorsa M. Toluene workers and chromosome aberrations. $J$ toxicol environ health 6 (1980) $775-781$.

37. Maugh TH. Chemicals: How many are there? Science 199 (1978) 162.

38. McCoy EC, Hankel R, Robbins $\mathrm{K}$, Rosenkrantz HS, Giuffrida JG, Bizzari DV. Presence of mutagenic substances in the urines of anesthesiologists. Mutat res $\mathbf{5 3}$ (1978) 71.

39. Meretoja $T$, Vainio $H$, Sorsa $M$, Härkönen $H$. Occupational styrene exposure and chromosomal aberrations. Mutat res 56 (1977) 193-197.

40. Møller M, Dybing E. Mutagenicity studies with urine concentrates from coke plant workers. Scand j work environ health 6 (1980) 216-220.

41. Monster AC. Biological monitoring of industrial solvents: Tetrachloroethylene. In: Aitio A, Riihimäki V, Vainio $\mathrm{H}$, ed. Biological monitoring and surveillance of workers exposed to chemicals. Hemisphere, New York, NY (in press).

42. Musilova J, Michalova K, Urban J. Sisterchromatid exchanges and chromosomal breakage in patients treated with cytostatics. Mutat res 67 (1979) 289-294.

43. Nielsen J, Friedrich U, Tsuboi T. Chromosome abnormalities in patients treated with chlorpromazine, penphenazine and lysergide. $\mathrm{Br}$ med j 3 (1969) 634-636.

44. Norppa $H$, Sorsa $M$, Vainio $H$, Gröhn P, Heinonen E, Holsti LR, Nordman E. Increased sister chromatid exchange frequencies in lymphocytes of nurses handling cytostatic drugs. Scand $j$ work environ health 6 (1980) 299-301.

45. Nowell PC. Biological significance of induced human chromosome aberrations. Fed proc 28 (1969) 1797-1803.

46. Osterman-Golkar S, Ehrenberg L, Segerbäck D, Hällström I. Evaluation of genetic risks of alkylating agents: II. Haemoglobin as a dose monitor. Mutat res 34 (1976) 110.

47. Osterman-Golkar S, Hultmark D, Segerbäck D, Calleman CJ, Göthe R, Ehrenberg $\mathrm{L}$, Wachtmeister CA. Alkylation of DNA and proteins in mice exposed to vinyl chloride. Biochem biophys res commun 76 (1977) $259-266$.

48. Pagé $M$, Thériaulth $L$, Delorme F. Elevated CEA levels in polyvinyl chloride workers. Biomédecine 25 (1976) 279.

49. Petres J, Schmid-Ullrich $\mathrm{K}$, Wolf $U$. Chromosome aberrations in human lymphocytes in the case of chronic arsenic injuries. Dtsch Med Wochenschr 95 (1970) $79-80$.

50. Poirier MC, Dubin MA, Yuspa SH. Formation and removal of specific acetylaminofluorence - DNA adducts in mouse and human cells measured by radioimmunoassay. Cancer res 39 (1979) 1377-1381.

51. Schwanitz G, Lehnart G, Beghart E. Chromosomenschaden bei beruflicher Bleiblast- 
ung. Dtsch Med Wochenschr 95 (1970) 1636-1641.

52. Segerbäck D, Calleman CJ, Ehrenberg L, Löfroth G, Osterman-Golkar S. Evaluation of genetic risks of alkylating agents: IV. Quantitative determination of alkylated amino acids in haemoglobin as a measure of the dose after treatment of mice with methyl methanesulfonate. Mutat res 49 (1978) $71-82$.

53. Siebert D, Simon U. Cyclophosphamide: Pilot study of genetically active metabolites in urine of a treated human patient. Mutat res 19 (1973) 65-72.

54. Stevenson AC, Bedford J, Hill AGS, Hill FHF. Chromosomal studies in patients taking phenylbutazone. Ann rheum dis 30 (1971) $487-500$.

55. Tola S, Kilpiö J, Virtamo M, Haapa K. Urinary chromium as an indicator of the exposure of welders to chromium. Scand j work environ health 3 (1977) 192-202.

56. Vainio H, Savolainen H, Kilpikari I. Urinary thioether of employees of a chemical plant. $\mathrm{Br} \mathrm{j}$ ind med 35 (1978) 232-234.

57. Viczian M. Ergebnisse von Spermaunter-

Received for publication: 20 May 1981 suchungen bei Zigarettenbrauchern. Haut Geschlechtskr 44 (1969) 183-187.

58. Vigliani EC, Saita G. Benzene and leukemia. Ny j med 271 (1964) 872-876.

59. Whorton D, Milby $T$, Krauss $R$, Stubbs $H$. Testicular function in DBCP exposed pesticide workers. $J$ occup med 21 (1979) 161166.

60. Wyrobeck A, Bruce R. The induction of sperm-shape abnormalities in mice and humans. In: Hollaender A, de Serres F, ed. Chemical mutagens. Volume 5. Plenum Press, New York, NY 1979, pp 257-285.

61. Yamasaki E, Ames B. Concentration of mutagens from urine with the nonpolar resin XAD-2: Cigarette smokers have mutagenic urine. Proc natl acad sci usa 74 (1977) 3555-3559.

62. - Altistumismittaukset ja kliiniskemialliset analyysit [Biological exposure tests and clinical chemistry analysis]. Institute of Occupational Health. Helsinki 1980, pp 1-70.

63. - Proceedings of the first international conference on the clinical uses of carcinoembryonic antigen. Cancer 42 (1978): suppl 3. 